\title{
Citizens United v The Federal Election Commission, Inverted Totalitarianism and Contemporary Fiction
}

Cory R. Chambers

Portland State University

Follow this and additional works at: https://pdxscholar.library.pdx.edu/mcnair

Part of the Modern Literature Commons, and the Russian Literature Commons Let us know how access to this document benefits you.

\section{Recommended Citation}

Chambers, Cory R. (2017) "Citizens United v The Federal Election Commission, Inverted Totalitarianism and Contemporary Fiction," PSU McNair Scholars Online Journal: Vol. 11: Iss. 1, Article 2. https://doi.org/10.15760/mcnair.2017.03 
Portland State University McNair Research Journal 2017

\title{
Citizens United v The Federal Election Commission, Inverted Totalitarianism and Contemporary Fiction
}

\author{
By \\ Cory Chambers \\ Faculty Mentor: Dr. Jennifer Ruth
}

Citation: Chambers, C. and Ruth, J. Citizens United $v$ The Federal Election Commission, Inverted Totalitarianism and Contemporary Fiction. Portland State University McNair Scholars Online Journal, Vol. 11, Year: 2017 


\section{Abstract}

In this paper I will explore the results of the 2010 Supreme Court Citizens United vs The Federal Election Commission as reflected in the contemporary literature. I will look at the role the corporation plays in American politics post Citizens United. My primary texts is the novel Super Sad True Love Story. My research question is: did the Citizens United decision open the door for 'inverted totalitarianism' to seep through the cracks of American society Using the allegorical novel Super Sad True Love Story by Gary Shteyngart, I will show how Citizens United, the political theory of Hannah Arendt, and the novel parallel and reflect the reality of our culture; where the weight of corporate oppression squashes the individual leaving that person simultaneously exposed and in complete loneliness.

Keywords: Super Sad True Love Story, Gary Shteyngart, Citizens United, Inverted Totalitarianism 


\section{Introduction}

American democracy in the mid twenty-first century is being threatened by a corporate backed autocracy. "Democracy is a difficult concept to tie down...Its meaning is slippery and allusive," says Peter Murphy in his essay Socialism and Democracy. Murphy continues, "We can probably agree upon a minimal content for the idea of democracy viz. that it means that all persons have a share in government; that no class or party or group monopolizes the state" (12). While the Supreme Court's decision on the Citizens United $v$. The Federal Election Commission seems innocuous, it allows for inverted totalitarianism to seep into democracy. As with traditional forms of totalitarianism the individual is deprived of her ability to participate in the democratic process, leaving the individual powerless. Only inverted totalitarianism puts the corporation at the helm instead of a traditional governmental regime. In her essay, On the Nature of Totalitarianism, Hannah Arendt states, "The dependence and interdependence which we need in order to realize our power (the amount of strength which is strictly our own) becomes a source of despair whenever, in complete loneliness, we realize that one man alone has no power at all but is always overwhelmed and defeated by superior power" (336). Was Arendt's statement a prediction? Using the allegorical novel Super Sad True Love Story by Gary Shteyngart, I will show how Citizens United, the political theory of Hannah Arendt, and the novel parallel and reflect the reality of our culture; where the weight of corporate oppression squashes the individual leaving that person simultaneously exposed and in complete loneliness.

\section{Citizens United v. The Federal Election Commission}

January 21,2010 , is the date that dramatically changed the American political system, a change that threatens the foundation of our democracy. On this date the United States Supreme Court announced their decision on the Citizens United v. The Federal Election Commission case. The 5-4 decision undermines and in some cases voids decades of campaign finance legislation, the very legislation that protects the political system from blatant corruption and domination. In essence the decision grants corporations the status of an individual citizen, without seeming to consider the extreme disparity of power that money buys. The ruling not only gives the corporation unprecedented status, but it shifts priority to their shareholders, including foreign investors. The ruling awards the corporation superior power over the singular American citizen and our political system.

One of the most powerful forces in American politics and business are the Koch brothers. In her book Dark Money, author Jane Mayer exhaustively explores the impact corporations, especially Koch Industries, has on our political system. Here is how Mayer introduces the brothers when they took charge of Koch Industries in 1967:

Charles and David - often referred to as the Koch brothers - owned virtually all of what had become under their leadership the second largest private company in America. They owned four thousand miles of pipelines, oil refineries in Alaska, Texas, and Minnesota, The Georgia-Pacific lumber and paper company, coal, and chemicals, and they were huge traders in commodity futures, and other businesses. The company's consistent profitability had made the two brothers the sixth- and seventhwealthiest men in the world. Each was worth an estimated \$14 billion in 2009 (2).

In addition to being two wealthy men who own multinational corporations they have an intense dislike for our system of government. Here Mayer describes the hatred the brothers have for anything not libertarian in nature, "the Kochs waged a long and 
remarkable battle of ideas. They subsidized networks of seemingly unconnected think tanks and academic programs and spawned advocacy groups to make their arguments in the national political debate" (3). More relevant to my argument than their political platform, the brothers spent monies to challenge voter protection laws and set new precedent in the courts, as Mayer goes on to say, "[The Koch Brothers] financed legal groups and judicial junkets to press their cases in the courts. Eventually, they added to this private political machine that rivaled and threatened to subsume the Republican Party" (3). In fact, the Koch brothers are not just threatened by the Republican Party, they succeeded in sowing seeds of discord, creating gridlock in congress and in fighting amongst the Republican Party. The party is now tearing itself apart, as is apparent in the 2016 Presidential election. The dissension amongst the Republican Party made way for the extreme candidacy of President Donald Trump. Although President Trump did not receive money from the Koch brothers, he did run his campaign on the Koch Brothers platform of xenophobia, anti-regulation, and hatred of all things related to sitting President Barack Obama, the Democratic Party and the Republican party. However, President Trump's extremism terrifies the entities that created space for him to run, and the Republican establishment and the Koch Brothers were quick to distance themselves from Trump. Author Stephen King speaks to the Donald Trump candidacy, "Conservatives who for eight years have sowed the dragon's teeth of partisan politics are horrified to discover they have actually grown a dragon."

The Koch Brothers are by no means the only wealthy heads of multinational corporations working in secrecy to subvert our democratic system and disempower the citizenry. In his New York Times article, "Club of the Most Powerful Gathers in Strictest Privacy," author David Kilpatrick states, "Three times a year for 23 years, a little-known club of a few hundred of the most powerful conservatives in the country have met behind closed doors at undisclosed locations for a confidential conference, the Council for National Policy, to strategize about how to turn the country to the right" (1). Now that Citizens United is in place, these powerful people, in secret meetings are strategizing how to spend billions of dollars electioneering races that range from Presidential to the State. This new system of politics is what Sheldon Wolin calls "Inverted Totalitarianism" and he describes inverted totalitarianism as this, "Inverted totalitarianism is only in part a statecentered phenomenon. Primarily it represents the political coming-of-age of corporate power and the political demobilization of the citizenry" $(x)$.

\section{American Restorations Authority}

Seven months after Citizens United Gary Shteyngart's totalitarian novel Super Sad True Love Story was released. Shteyngart presents an inept vaguely familiar American government in the midst of collapse. Comprised of caustic consumers, filled with anxiety regarding their jobs and credit rating, they are overwhelmed by the surveillance state; Shteyngart's citizens are prostrate to the Bipartisan party, the American Restoration Authority (ARA), and all corporations. This version of America is not dissimilar to Twenty-first century America, where as economist Annie McClanahan states, "Real median family income failed to rise for the first time in post-war history while everything from housing to health care to education was becoming more and more unaffordable. Households were thus increasingly dependent on the availability of ready consumer credit" (83). The consumer centric ARA leadership displays a person's credit score on poles - not unlike telephone poles - as said person passes by. Shteyngart includes government approved instructions to the consumer, "The Boat is Full, Avoid Deportation, Latinos Save, Chinese Spend, ALWAYS Keep Your Credit Ranking Within Limits," (54) along side projected credit scores. These slogans imply that the citizen can be deported for poor credit and the instructions are divided along lines of race. Shteyngart further 
divides the population into High Net-Worth Individuals (HNWIs) and Low Net-Worth Individuals (LNWIs). Shteyngart's early focus on credit and the financialization of the citizen sets the stage for the great gulf between those with all the money and those with none.

Once the financial hierarchy is established, - the business of reducing the rights of LNWIs - dehumanizing and justified killing of citizens begins. In the "Decline of NationState and the End of Rights of Man" section of The Origins of Totalitarianism, Hannah Arendt asserts, "For the nation-state cannot exist once its principle of equality before the law has broken down" (290). As the ARA embraces the breakdown of "equality" they increase the use of violence. Lenny Abramov, the protagonist of Super Sad True Love Story describes learning of a "riot" in Central Park: "This black dude is getting his ass kicked by the Guard and all these LNWIs are getting seriously whaled on" (156). This scene is poignant because it is the point where violent, physical domination of LNWIs begins. It is as Arendt predicted "the principle of equality before the law," that has completely broken down. Lenny and his friends - who financially are protected by their credit ratings and employment - view the riot from a place of safety: "News of the Central Park slaughter was spreading through the bar. No one was streaming live yet, but there were Images coming up on our äppäräti and on the bar's big screens" (156). The images seem to be ghosts from Nazi Germany that have come back to haunt Lenny and his friends, "The bodies of three men and a woman (a family?) lying on their backs, their naked black arms thrown wildly across their bodies, as if haphazardly hugging themselves" (156). Shteyngart uses this terrifying image to make his point; the image of dead bodies slung on top one another is ingrained in the world's collective memory. With just a few sentences, Shteyngart solidifies the fate of LNWIs and simultaneously warns the rest of his fictional population of the urgent need to conform. The riots end with this message from the ARA, "NOW IS THE TIME FOR SPENDING, SAVING, AND UNITY. ONE PARTY, ONE NATION, ONE GOD" (161).

Lenny, still shaken by the events in Central Park, returns to work at Post-Human Services, a subsidiary of Staatling-Wapachung Corporation. Lenny listens intently to a speech given by his boss Joshie Goldman, a powerful figure within the Wapachung corporation. "Pointless loss of life," Joshie says, and "loss of prestige for the country. Loss of tourist yuan. Loss of face for our leadership, as if they had any face to lose. And for what? Nothing has been achieved in Central Park. When will the Bipartisans realize that killing Low Net Worth Individual will not reverse this country's trade deficit or cure our balance-of-payment problems?'" (180). Joshie continues to pontificate about the damages caused by the ARA: "'We are finally no longer critically relevant to the world economy. The rest of the globe is strong enough to decouple from us. We, our country, our city, our infrastructure, are in a state of freefall'" (181). While accounting for the failing state, Joshie also protects his position amongst the elite with this statement, "We must remind ourselves of the Fallacy of Merely Existing, which restricts what we can do for a whole sector of people. Yet, even though we may absolve ourselves of responsibility, we, as a technological elite can set a good example" (181). Joshie is not concerned with humanity and is willing to dismiss an entire group of people solely because they only exist and in his views do not contribute to the new regime.

\section{Staatling-Wapachung Corporation: Assumes Control}

In Origins of Totalitarianism, Arendt states, "Nothing is more characteristic of the totalitarian movements in general and of the quality of fame of their leaders in particular than the startling swiftness with which they can be replaced" (306). This statement rings true in the fact that shortly after Joshie Goldman's "state of the things" speech, the 
Bipartisan Party and the ARA fall and are "swiftly" replaced by the Staatling-Wapachung Corporation.

The Wapachung Corporation quickly assumes ultimate power and control of the United States - the type of power only obtained by the corrupting forces of the elite, the corporation the very entity the United States Supreme Court made a citizen on that fateful January day.

The Wapachung Contingency begins their reign by assuaging the fears of their shareholders and executives with this statement, "We at Staatling-Wapachung are reaching out to other nations' sovereign wealth funds looking for investment and alliance. We anticipate social changes that will benefit all shareholders and top-level personnel" (240). Following the reassurance that the shareholder's money is safe, Wapachung then asserts its power of protection with an announcement: "Wapachung Contingency personnel have been instructed to protect you from rioting Low Net Worth Individuals and Rogue National Guard elements" (240). Shteyngart's corporation assumes control. First, by protecting the share holders as well as looking to foreign monies to prop up the government. Second, the Wapachung personal military supplants the American National Guard thus depriving the individual of a security force put in place by elected officials.

One campaign finance law that, in theory, survived Citizens United is that no foreign entity or government can directly contribute to American election campaigns. The knowledge that foreign entities invest in American corporations did not escape the attention of the Supreme Court. Justice Ruth Bader Ginsburg asked, "Would that include today's mega corporations, where many of the investors may be foreign? A week later, in his 2010 State of the Union speech, President Barak Obama echoed Justice Ginsburg's fears saying, "I don't think American elections should be bankrolled by America's most powerful interests, or worse, by foreign entities." Justice Ginsburg and President Obama are referring to the Citizens argument that the shareholder, and by extension the corporation, has a right to free speech, that the corporation should have unrestricted access to the political system as a function of Constitutional Rights.

Wherever there is a political collapse there is also a military force or secret police at the ready. In Super Sad True Love Story that force belongs to the aforementioned StaatlingWapachung corporation. The message sent to employees and shareholders assures protection. As an employee, Lenny is given a Wapachung escort to visit his family in Long Island. The leader of the escort tries to comfort Lenny on the journey by saying, "Anyway, we are armed to the teeth, so no worries, We've got a heavy .50 caliber M2 Browning machine gun on the lead vehicle and AT4 anti-armor on both" (285). Here it becomes clear that the Staatling-Wapachung Contingency is the dominant military force. There is evidence, outside of fiction, that powerful American corporations have undue political power and military might. One of Meyer's most frightening examples of a corporation corrupting the system is in the story of the DeVos family, better know as the Amway Corporation. The DeVos family and Amway have strong foreign ties, "By 2006, fully a third of Amway's revenue came from the [Chinese] communist state" (234). This alone justifies Justice Ginsburg's fear of foreign interests playing out in the American Political system.

However, the most disturbing power of the DeVos family is its access to a para military. Richard (Dick) DeVos married Betsy Prince. While a marriage of power might be harmless, this one is treacherous as Betsy Prince (Devos) is not only President Trumps Secretary of Education, but the sister of Erik Prince the founder of Blackwater, a 
paramilitary force. Here is what Meyer says about the marriage: "Her brother Erik Prince, meanwhile, founded the global security firm Blackwater, which reporter Jeremy Scahill described as 'the world's most powerful mercenary army" (234). Amway and Blackwater are the real life version of the Staatling-Wapachung and their ties prove a point that Hannah Arendt makes in her essay, On the Nature of Totalitarianism: "In totalitarian states, neither army nor church nor bureaucracy was ever in a position to wield or to restrain power; all executive power is in the hands of the secret police" (347).

\section{The Americans}

"A person who has been seduced by the consumer values system, whose identity is dissolved in an amalgam of the accoutrements of mass civilization, and who has no roots in the order of being, no sense of responsibility for anything higher than his own personal survival, is a demoralized person," states Václav Havel in his essay The Power of the Powerless; "The system depends on this demoralization, deepens, is in fact a projection of it into society" (45) The culture of Super Sad True Love Story is in the throes of seduction by the consumer value system. The citizens have attached themselves to their technology, the äppäräti, through which they purchase commodities, monitor and judge each other. Each person has access to another's most personal information through technology without speaking a single word to another. Shteyngart calls this process "FAC...it means 'Form a Community'" (88). This process reveals not only Lenny's ZIP code, but his blood pressure, aggregated wealth, liabilities and assets. It also shockingly exposes Lenny's sexual preferences for women who have been sexually abused and have low self-esteem. Citizens (both real and fictional) participate in the dissemination of demoralizing information.

What Shteyngart calls FAC, technologist Maciej Ceglowski calls "surveillance capitalism". Ceglowski explains surveillance capitalism in his June 2016 speech to The Society for the Social Advancement of Socio-Economics, "Surveillance capitalism has some of the features of a zero sum game. The actual value of data collected is not clear, but it is definitely an advantage to collect more than your rivals do. Because human beings develop an immune response to new forms of tracking and manipulation, the only way to stay successful is to keep finding new and novel ways to peer into people's private lives." While Ceglowski is not speaking of Shteyngart's novel, he also concludes that technology leads to an isolated yet trackable citizen. Ceglowski also speaks to the idea of not using invasive technology, "opting out of surveillance capitalism like opting out of electricity, or cooked foods - you are free to do it in theory. In practice, it will up end your life." In an early scene of Super Sad True Love Story Lenny observes the uncomfortable results of a person choosing to opt out, Lenny notes that: "He didn't have an äppärät, or it wasn't set on 'social' mode." Lenny later continues the narrative of this non-social man being pulled off an airplane as the man yells, "What did I do? Look at my wallet. I'm Bipartisan" (40). Lenny, quiet and afraid, sneaks a glance at the military men removing the offender from the plane, "standing evenly around him, fingers on triggers" (40).

Technology is a key player in Super Sad True Love Story. It is the way in which people communicate and are tracked by the ARA and the Staatling-Wapachung.

Technology as it exists in modern societies gives the illusion of connection. Facebook, Instagram, Snapchat and a host of other platforms allow citizens to feel as if they are participating in each others' lives. While the opposite is true, we have become selfabsorbed voyeurs. We pass through mountains of data without interacting in an honest 
face to face fashion. Shetyngart accurately captures this phenomenon in this scene: "All you could hear were the whirs and clicks of our äppäräti downloaded and the competing chirping of the cicadas emerged from their seven-year slumber. And the looks on the faces of our countrymen-passive heads bent, arms at their trousers, everyone guilty of not being their best, of not earning their daily bread, the kind of docility I never expected from Americans, even after so many years of decline" (130). Even as Lenny and his friends walk through dehumanized, soon to be dead soldiers, they do not verbally interact, instead they let the äppäräti 'whir and click' and collect data to be viewed at an emotionally safe distance. Technology changes people, for example, Lenny's friend Noah, using his äppärät broadcasts a constant stream of his daily actions and meetings and the Noah Weinberg Show is sponsored by "a former Bipartisan politician who now ran security consulting for the Wapachung Contingency, the wellarmed security division of [Lenny's] employer" (85). Lenny notes that Noah has changed: "Noah, hadn't always been this angry and caustic, but there was something disproportionate about his efforts these days, as if he could no longer keep track of how his personal decline paralleled that of our culture" (85). This early description of Noah is particularly telling as Shteyngart continues to illustrate decline throughout the rest of the novel as it parallels modern American culture.

The most poignant example of the demoralization of a population in Super Sad True Love Story is presented in the form of an art opening, or what Lenny refers to as a "Chinese welcoming party" sponsored by Wapachung Contingency. The exhibit "purposely zoomed in on the living, or, to be more accurate, the forced-to-be-living and the soon-to-be dead" (318). Lenny describes the art, or proof of humanities demise, in great detail, "An old man from Wichita without eyes, with the eyes physically removed, with one of the eyeholes being forced open by a laughing young man" (318). Lenny is seeing this art from the safe distance of an art gallery complete with refreshments. Again, in his June 2016 speech Maciej Ceglowski describes the current state of affairs in a wealthy, tech and corporate driven society saying, "Take a stroll through downtown San Francisco and try to persuade yourself you're in the heart of a boom that lasted for forty years. You'll see a residential theme park for tech workers, surrounded by areas of poverty and misery that have seen no benefit and ample harm from our presence." While this statement lacks the gravity presented at Shteyngart's "art opening" it is an echo of the past and future where humanities depravity is always on display.

\section{Conclusion}

The future of modern America rests on the precipice between a failing democracy and inverted totalitarianism. Sheldon Wolin's timely definition of inverted totalitarianism is: Inverted totalitarianism works differently. It reflects the belief that the world can be changed to accord with a limited range of objectives, such as ensuring that its own energy needs will be met, that 'free markets' will be established, that military supremacy will be maintained, and 'friendly regimes' will be in place in those parts of the world considered vital to its own security and economic needs (47)

Super Sad True Love Story successfully supports Wolin's definition, wherein Wapachung maintains the free market, a military force, and relations with China that benefit its 'own economic needs'. The Koch brothers and their ilk maintain the same beliefs and needs described by Wolin. Just as a modern corporation benefits from Citizens United so would the fictional Staatling-Wapachung corporation.

Our society continues to cede power and information to the corporation, be it Apple, Facebook, Twitter or Instagram, with surveillance capitalism and the political power derived from the Citizens United decision. Wolin explains, "The acceptance of restraints on personal freedom and being resigned to political impotence: such possibilities are not 
wildly implausible for a society that is accustomed to exchanging new habits for old, to adapting to rapid change, uncertainty, and social dislocation, to having one's fate determined by distant powers" (42). The more freedoms we give up as citizens, the more reliant upon technology we are then the more isolated we become, leaving us in a disempowered state. In Origins of Totalitarianism, Arendt describes our future by reflecting on France, "she had no more true Dreyfusards, no more who believed that democracy and freedom, equality and justice could any longer be realized under the Republic" (93). The Dreyfusards that Arendt refers to are a group of French citizens who pushed against an unjust court ruling. The result is they lost faith in their government, they became hopeless, and left adrift in loneliness. If the ruling of Citizens United stands and the power of the corporation continues to increase exponentially, then the American citizens will no longer believe in the republic and will be "consumed by a 'superior power' and we will fall to inverted totalitarianism. All of these texts demonstrate that to fail to restrain the power of corporations will lead to the disempowered and alone individual of the state, resulting in a power vacuum that will consume us all in totalitarianism. 


\section{Work Cited}

Arendt, Hannah. The Origins of Totalitarianism. New York. Harcourt, 1973. Print

Boedecker, Karl A. "Corporate speech and the problem of corporate personality in Citizens United v. Federal Election Commission." Journal of Legal, Ethical and

Regulatory Issues 17.1 (2014): 37+. General OneFile. Web. 10 July 2016

Ceglowski, Maciej. "Remarks at the SASE Panel On The Moral Economy of Tech."

Remarks at the SASE Panel On The Moral Economy of Tech. Society for the Social Advancement of Socio-Economics, 26 June 2016. Web. 25 July 2016.

"Citizens United v. Federal Election Commission." Oyez. Chicago-Kent College of Law at Illinois Tech. Web 9 August 2016

. The Power of the Powerless: Citizens against the state in central-eastern Europe. New Yor. M.E. Sharpe, 1985. Print

Kirkpatrick, David. "Club of the Most Powerful Gathers in Strictest Privacy." The New York Times, 27 Aug. 2004. Web. 24 July 2016.

Mayer, Jane. Dark Money: The Hidden History of the Billionaires behind the Rise of the Radical Right. New York: Doubleday, 2016. Print.

McClanahan, Annie. "Investing in the Future" Journal of Cultural Economy, 6:1 (2013):78-93. Web 2 Feb. 2016.

Murphy, Peter. "Socialism and Democracy." Between Totalitarianism

andPostmodernity: A Thesis Eleven 26 Reader. Cambridge: MIT, 1992. 12-31. Print.

Obama, Barak. "Remarks by the President in State of the Union Address." The White House. The White House, 27 Jan. 2010. Web. 25 July 2016.

Silver, David. "Business Ethics After Citizens United: A Contractualist Analysis." Journal of Business Ethics 127.2 (2015): 385-97. ProQuest. Web. 17 Jan. 2016.

Shteyngart, Gary. Super Sad True Love Story. New York. Random House, 2010. Print.

Wolin, Sheldon S. Democracy Incorporated: Managed Democracy and the Specter of Inverted Totalitarianism. Princeton: Princeton UP, 2008. Print. 